\section{Superconductors in Power Plants}

Sir,--In my article discussing engineering limitations of superconductors in power plant (Nature, 219, 1317; 1968) I said that excitation of the International Research and Development 3,250 horse-power superconducting homopolar machine could be achieved with conventional conductors and for the $£ 40,000$ cost of helium refrigeration plant.

I regret that an analysis which led me to this conclusion proves to be wrong and I wish both to withdraw this comment and to apologize for any confusion that it may have caused.

$$
\text { Yours sincerely, }
$$

$$
\text { K. J. R. WILKINSON }
$$

The General Electric Co. Ltd,

Hirst Research Centre,

Wembley, Middlesex.

\section{Evaluation of 'Alcotest R80' Reagent Tubes}

Sir,- Although the design and execution of their study of the 'Alcotest'1 were impeccable, I suggest that Messrs Day, Muir and Watling are somewhat unfair to the device in their discussion and conclusions.

They state that their aim was "to evaluate the use of the 'Alcotest' tubes as a means of enforcing the $80 \mathrm{mg}$ limit" and suggest that "it would be better for a blood test to be taken". In fact, of course, a blood test is always taken if the two 'Alcotest' results are positive, and the 'Alcotest' is not used for enforcement but for screening purposes only, as suggested by the OECD report that they quote.

Their conclusion that, even as a screening test, the 'Alcotest' would be unacceptable is open to question. The usefulness of a screening test depends at least as much on the circumstances under which it is used as on its accuracy and precision. 'Their figures suggest that the 'Alcotest' allows very few people over the limit to escape, which is obviously desirable, for the $80 \mathrm{mg}$ limit is well above the levels reached in normal social drinking ${ }^{2}$. Whether the relatively high false positive rate is too great a price to pay for this is a matter of opinion. It could obviously be reduced by making the test less sensitive, but only at the cost of allowing a larger proportion of the guilty to escape. Moreover, it is likely that the test is less sensitive in the hands of the police than when used by careful experimenters working in the laboratory, because, apart from possible differences of reading criteria, almost all technical errors lead to a low result ${ }^{3}$.

The test might, however, be made more precise by providing for an end tidal breath sample instead of mixed expired air as at present ${ }^{3}$. A simple and inexpensive device for doing this has been described ${ }^{4}$, but because it requires the subject to give a larger breath sample it increases the probability of a subject elaiming to be, or being, genuinely unable to give a proper sample.

Although to have a serious charge hanging over one's head for up to 3 weeks is an unpleasant experience, the persons concerned are by no means absolutely guiltless. To have a sustained blood alcohol even as low as $30 \mathrm{mg}$ they must have consumed a substantial amount of alcohol, and they must then have committed a moving traffic offence or have been involved in an accident. The reduction in fatal and serious accidents that has occurred since the Act came into force has been such that this small defect in its administration seems trivial by comparison.

$$
\text { Yours faithfully, }
$$

$$
\text { B. M. WRIGHT }
$$

National Institute for Medical Research,

Mill Hill,

London NW7.

${ }^{1}$ Day, M., Muir, G. G., and Watling, J., Nature, 219, 1051 (1968).

2 Wright, B. M., Brit. Med. J., 1, 814 (1963).

${ }^{s}$ Grosskopf, K., Alcohol and Road Traffic, BMA, 281 (1963).

Wright, B. M., J. Physiol., 184, 66 (1966)

\section{University News}

Dr K. Simkiss, Reading, has been appointed to the chair of zoology tenable at Queen Mary College, London. The title of professor has been conferred on the following: Dr A. G. Davies, chemistry, in respect of his post at University College; Dr P. J. Lawther, environmental medicine, in respect of his post at $\mathbf{S t}$ Bartholomew's Hospital Medical College ; Dr A. P. Willmore, physics, in respect of his post at University College.

\section{Appointments}

Professor W. A. Hiltner, professor of astrophysics at the University of Chicago, has been elected president of the Association of Universities for Research in Astronomy.

Mr G. H. Caldwell has been appointed chief of the Water Survey of Canada, a division of the Department of Energy, Mines and Resources.

Mr J. Blears, chief engineer of the Scientific Apparatus Department, GEC-AEI, has been appointed first permanent director of industrial studies in the University of Liverpool.

Dr R. B. Tibby has been appointed director of the Catalina Marine Science Center in the University of Southern California.

Corrigendum. In the communication "New Method to Limit Abundance of Cosmic Ray Quarks" by L. Marshall Libby and F. J. Thomas (Nature, 219, 711; 1968) the second equation in appendix 4 should read $1 / T=(4 / 3)$ $\left(\omega^{3} \mathrm{e}^{2} / \mathrm{h} c^{3}\right) r^{2}=\frac{1}{\left(3 \times 10^{-12} \mathrm{~s}\right)}$. The tenth line from the bottom of the same appendix should read "For $Q^{-2 / 3}, Q^{-4 / 3}$, $Q^{-5 / 3}, \ldots$ the chains may be shorter".

ERratum. In the advertisement for George T. Gurr (Nature, August 24, 219, ix; 1968) the address should read 14 Carlisle Road, The Hyde, London, NW9. Tel.: 01-205-5432.

Erratum. In the issue of August 10 (Nature, 219, xi; 1968) the price of the book Positive Feedback by John Milsum, published by Pergamon Press, Ltd, was incorrectly given as $52 s$. It should be $52 s .6 d$.

Erratum. In Fig. 1 of the article "Significance of Sex Chromosome Derived Heterochromatin in Mammals" by J. L. Hamerton (Nature, 219, 910; 1968) the words "cortical stimulation" and "medullary stimulation" immediately under the $X X$ and $X Y$ chromosomes have become transposed. Medullary stimulation refers to the $X Y$ gonad and cortical stimulation to the $X X$ gonad and not as shown. On page 913 the last sentence of paragraph 4 should read ". . . and it may be that, like the $t$-alleles in the mouse ${ }^{44,45}$, it should be considered as a short chromosome region rather than as a single gene".

ERratum. The cpening sentence of the communication, "Rosette Forming Cells in Non-immunized Mice" by R. Laskov (Nature, 219, 973; 1968), should read "Antibody" producing cells can be detected...".

ERratum. In the communication, "Particles associated with Australia Antigen in the Sera of Patients with Leukaemia, Down's Syndrome and Hepatitis" by Manfred E. Bayer, Baruch S. Blumberg and Barbara Werner (Nature, 218, 1057; 1968), the second sentence of the sixth paragraph should read "The antiserum produced in the rabbit was prepared by immunization with the serum of a patient (C. de S.) suffering from chronic lymphocytic leukaemia; subsequently the antiserum was absorbed with the sera of normal individuals". 


\section{International Meetings}

October 23, Computer Simulation of Plant Growth, National Vegetable Research Station, Wellesbourne (Allen Cooper, Convenor, Plant Physiology Group, Glasshouse Crops Research Institute, Worthing Road, Littlehampton, Sussex).

November 4-7, Techniques of Data Handling for Tactical Systems, Amsterdam (Avionics Panel, Advisory Group for Aerospace Research and Development, 7 rue Ancelle, 92 Neuilly-sur-Seine, France).

November 4-8, Operational Research in Electrical Power Systems, Athens (HELORS Conference Oreps, Gen. R. Spanoyannakis, Kapodistriou 28, Athens 147, Greece).

November 4-9, 15th annual meeting of International North Pacific Fisheries Commission, Seattle (6640 Northwest Marine Dr., Vancouver 8, BC, Canada).

November 4-12, Biology and Nuclear Medicine, Buenos Aires (Dr V. Pecorini, Association Argentina de Biologia y Medicina Nuclear, Avda, Santa Fe 1145, Buenos Aires, Argentina).

November 7-9, Sodium Technology, Argonne Laboratory (Dr D. Okrent, Director's Office, 9700 South Cass Av., Argonne, Illinois 60439, USA).

November 10-16, Zoology, Caracas (C. E. MachadoAllison, Secretary, c/o University of Caracas, Caracas, Venezuela).

November 10-December 23, Geographical Congress, New Delhi (Professor S. Chatterjee, President, International Geographical Union, c/o National Atlas Organization, 1 Acharya Jagadish Bose Road, Calcutta 20, India). November 11-13, Economic Geologists, Mexico (Robert A. Laurence, Secretary, PO Box 1549, Knoxville, Tennessee, USA).

November 11-14, Aircraft Cockpit Environment, Amsterdam (Avionics Panel, Advisory Group for Aerospace Research and Development, 7 rue Ancelle, 92 Neuilly-sur-Seine, France).

November 11-16, Arterial Hypertension, Buenos Aires (Dr Alberto C. Taquini, jun., Montevideo 1390, Buenos Aires, Argentina).

November 12-13, Ghill-casting for Ferrous Metals, Yeipzig, H. Hoffmeister, c/o Zentralinstitut fur Giessereitechnik, Gerhard-Ellrodtstr. 24, 7034 Leipzig, Germany). November 18-21, Cellular Plastics Conference, New York (Dr S. Steingiser, c/o Monsanto Research Corporation, Station BPO 8, Drayton, Ohio 45407, USA).

November 20-21, Epizootics, Scheveningen (Burgemeester de Monchyplein 14, The Hague, Netherlands).

November 20-26, Automation and Instrumentation Conference and Exhibition, Milan (Federazione delle Associazione Scientifiche e Techniche di Milano, Piazzale Rodolfo Morandi 2, 20121 Milan, Italy).

November 22-24, Occupational Health, Bombay (Dr J. C. Kothari, c/o Esso Standard Eastern, PO Box 355, Bombay 1, India).

November 25-30, Psychiatry, Bogotá (Committee Organizer, Aptd. Aereo 20553, Bogotá 2, Colombia).

November 26-27, Aerospace Exposition, Montreal (Dr B. G. Newman, c/o Department of Mechanical Engineering, McGill University, Montreal 2, Canada).

November 30-December 1, Pharmacological Treatment in Burns, Milan (Professor A. Bertelli, Società Italiana di Farmacologia Clinica, Via Vanvitelli 32, 20129 Milan, Italy).

December 16-20, Relativistic Astrophysics, Dallas (Ivor Robinson, Southwest Center for Advanced Studies, PO Box 30365, Dallas, Texas 75230, USA).

\section{FORTHCOMING EVENTS}

(Meetings marked with an asterisk are open to the public)

Monday, October 14

British Coal Utilization Research Association (at the Confederation of British Industries, 21 Tothill Strcet, London, SW 1), at 5.30 p.m.-Dr H. . Crossley: "Coal Science Techniques for the Electricity Generating Industry" (Seventeenth Coal Science Lecture).

Institction of EleCTrical Fnginekrs (at Savoy Place, London, WC2) at 5.30 p.m.-Dr H. E. Rowe "Propagation in a Random One-Dimensional
Medium".

Institution of Mechanical Fingineers, Fldid Plant and Machinery Grovp (at 1 Birdcage Walk, Westminster, London, SW1), at 6 p.m.-Discus sion mecting on "Standardization of the Performance and Dimensions of the

OIL AND Colour Chemists' Assoctation, Southern Branch (at Keppels' Head Hotel, Portsmouth), at 7.30 p.m.-Mr G. C. R. Russell: "Thick Coatings".

Monday, October 14-Friday, October 18

Instituiton OF ELECTRICAL EnGINEERS (at Savoy Place, London, WC2) Confcrence on "The Performance of Electrified Railways". (A Survey of

Tuesday, October 15

SOCIETY OF CHEMICAL INDUSTRY, Agriculture Group (at 14 Belgrave Square, I.ondon, SW1), at 10 a.m.-Meeting on "World Plant Nutrient Reserves and their Conservation".

Institution of EL ECTRICAL ENgINEers (at Savoy Place, London, WC2), at 5.30 p.m.- Mr P. G. Holmes and Mr J. G. Smithson: "The Development of an Improved Electric Trawl Winch Control for Stern Trawlers".

ROYAL INSTITUTION (at 21 Albemarle Street, London, W1), at 5.30 p.m.Mr E. Ironmonger: "Visual Topology", (Lecture for Sixth Form Boys and Girls from Schools in London and the Home Countics. To be repeated on October 16,22 and 23.)

INSTITUTION OF MECHANICAL ENGINEERS, AUTOMOBILE DIVISION (at 1 Birdcage Walk, Westminster, London, SW 1), at 6 p.m.-Annual Mecting. address)

UNIVERsity of London, Department of Extra MURal StUdies; and the LINNEAN SOCIETY OF LoNDON (at the Linnean Society, Burlington House, Piccadilly, London, W1), at 6.30 p.m.-Dr Errol I. White, FRS; "The Beginnings of Palaeontology". ('Third of twelve lectures on "The Historical Background to Modern Zoology".)

\section{Wednesday, October 16}

ROYAI INSTITUTION, HistoRy OF SCIENCE DISCUSSION GROUP (at 21 Albemarle Strect, London, W1), at 1 p.m.-Mr Frank Greenaway: "Animal

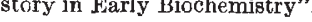

Institciton of ELECTRICAL ENGINEERs (at Savoy Place, London, WC2), at 5.30 p.m.-Discussion meeting on "The MSe-Devaluation or Revaluation?" opened by Dr B. Arrol and Professor H. A. Prime.

INSTIJ DTION OF ELECTRICAL ENGINEERS (at Savoy Place, London, WC2), at 5.30 p.m.- ProffEzor J. C. Anderson: "Thin Film Transistors".

institetion of Electronic and Radio Engineers, Aerospace, MariTIME AND MILITARY SYSTEMS GROUP (at 9 Bedford Square, London, WC1) at 6 p.m.-Mr S. S. D. Jones: "Airborne Collision Avoidance Systems".

INSTIT CIE OF REFRIGERATION (at the National College for Heating Ventilating, Refrigeration and Fan Engineering, Southwark Bridge Road,
London, SE1), at 6 p.m.-Mr James A. Brewster: Presidential address.

Institution OF MECHANICAI EngINEERS (at 1 Birdcage Walk, Westminster, London, SW1), at 6 p.m.-Discussion meeting on "Supercharging Vhicle Diescl Engines by the Comprex System".

SOCIETy OF Chemical IndUStry, Plastics and POLymer Group (at the Technical College, Glouccster), at 7.30 p.m.-Professor M. Gordon: "The Relationship Between Structure and Properties of High Polymers".

\section{Thursday, October 17}

Institution of Electronic and Radio Engineers, JoInt IERE/IEE COMPUTER GROCPS (at the Middlesex Hospital Medical School, Cleveland Street, London, W1), at 10 a.m. and 2 p.m.-Colloquium on "System Structures of Modern Computers".

SOCIETY OF CHEMICAI INDUSTRY, FOON GRONP (at the Royal Suciety, 6 Caritcn House Terrace, London, SW1), at 10 a.m.- Symposium on "New Institction of Mining and METai,i,dRgy (at the Geological society, Burlington House, Piccadilly, Iondon, W1), at 5 p.m.-Dr J.W. Norman: "Photogeology of Iinear Features in Areas covered with Superflcial Deposits"; Dr R. A. J. Shelton: "Thermodynamic Analysis of the Van Arkel Iodide Proccss"; and "Rate of Deposition of Zirconium in the Van Arkel odide Process".

INSTITUTION OF ELACTRYCAL ENGINEERS (at Savoy Place, London, WC2), at 5.30 p.m.-Discussion meeting on "Product Decision Making in the Fiectronic's Field".

INSTTUUTION OF ELECTRONIC AND RADIO ENGINEERS, COMMUNICATIONS GROUP (at 9 Bedford Square, London, WC1), at $6 \mathrm{pm}$-Mr E. R. Rout and Mr. A. H. Jones: "PCM for Point to Point Music Transmission".

SOCIETY OF CHEMrCAL INDUSTRY, Foon GROUP (joint meeting with RSH Food and Nutrition Section, and IVST, at the Royal Society, 6 Carlton House Terrace, J.ondon, SW'1), at 6.15 p.m.- Symposium on "New Sources and Forms of Protein for Human and Animal Nutrition".

OIL AND Colovr Chemists' Association (at University College London, Gower Street, London, WC1), at 6.30 p.m.-Mr G. S. Saunders: "Management by Objectives in Research and Development". 
ROYAL SOCIETY OF TROPICAL MEDICINE AND HYGIENE (at Manson House, 26 Portland Place, London, W1), at 7.30 p.m.-Dr F. Hawking, Mr M. J the Blood: Their Purpose "Production and Control".

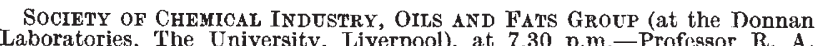
Laboratories, The University, Liverpool), at 7.30 p.m.-Professor R. A.

Thursday, October 17-Friday, October 18

Institution of Mechanical Engineers, Process Enginening Group (at 1 Birdcage Walk, Westminster, London, SW1) - Symposium on "Atmospheric Pollut

\section{Friday, October 18}

ROYAL SocieTy (at 6 Carlton House Terrace, London, SW1), at 10.30 a.m. -Discussion Meeting on "Scientific Information".

Royal Institution, Photochemistry Discussion Group (at 21 Albemarle Street, London, 'W1), at 1 p.m.-Dr J. Barrett: "Photochemistry of

ROYal INSTITUTION (at 21 Albemarle Street, London, W1), at 9 p.m.Professor R. V. Jones, FRS: "More and More about Less and Less".

Friday, October 18-Saturday, October 19

Pierre Teilhard de Chardin association ow Great Brttain and IRELANI) (at St. Pancras Assembly Rooms, Euston Road, London, NW1), at 5.30 p.m. on Friday and $9.30 \mathrm{a} . \mathrm{m}$. on Saturday-Conference on "Mankind

\section{Saturday, October 19}

BIOCHEMICAL SOCIETY (at the Unilever Research Laboratory, Colworth House, Sharnbrook, Bedford) -487th Meeting. Dr M. H. Richmond: "Fxtrachromosomal Genetic Elements and Evolution to Drug-Resistance in Bacterial Populations" (Fourth Colworth Medal Lecture).

\section{Monday, October 21}

Institution of Electrical Engineers (at Savoy Place, London, WC2), at 10 a.m.-Colloquium on "Electrical Passenger Vehicles".

Society of Chemical Industry, Pesticides Group (at 14 Belgrave Square, London, SW1), at 5 p.m.-Dr N. G. Morgan: "Spray Application
Efficiency in Fruit Crops".

INSTITUTION OF ElECTRICAL ENGINEERS, LONDON GRADUATE AND STUDENT SECTION (at Savoy Place, London, WC2), at 6.30 p.m.-Mr J. Miley: "Control of a Large Power System" (Chairman's Inaugural Address)

\section{REPORTS and other PUBLICATIONS}

\author{
(not included in the monthly Books Supplement)
}

\section{Great Britain and Ireland}

The Radiochemical Centre. Technical Bulletin 68/12: Radiation Sources for Detectors in Gas Chromatography. Pp. 2. (Amersham: The Radiohemical Centre, 1968.)

Philosophical Transactions of the Royal Society of London. Series A: Mathematical and Physical Sciences. No. 1140, Vol. 263 (20 August 1968) Characteristics of the Defocused Spherical Fabry-Pérot Interferometer as a Quasi-Linear Dispersion Instrument for High Resolution Spectroscopy of Pulsed Laser Sources. By D. J. Bradley and C. J. Mitchell. High Resolution Spectroscopy of Narrow Band Giant Pulse Lasers: Time-Dependent Frequency Shifts in Ruby. By D. J. Bradley, M. S. Engwell, A. W. McCullough Royal Society, 1968.) 258; $\$ 3.25$. Pp. 209-237+6 plates. (London: The Royal Society, 1968.) 258.; \$3.25. Fraud. By Tom Hadden. Pp. 273 $\sim 333$. (London: Political and Economic

[169
Planning, 1968.) 10s.

Research, 1968.) $5 s$. Wuilding and Works. Sand and Gravel Production 1966-67. Pp. 19. (London: H.M. Stationery Office, 1968.) 3s. net. [169 Cumbernauld 67: a Household Survey and Report. By Professor A. J. M. Sykes, Dr J. M. Livingstone and M. Green. Pp. 67. (Glasgow: Department
of Sociology, University of Strathclyde, 1968.) of Sociology, University of Strathclyde, 1968.)
Pictorial Science, Vol. 1, No. 1, October 1968. Pp. 24. (London: Evans Brothers, Ltd, 1968.) $4 s .6 d$.
B

\section{HOW TO BUY NATURE}

Volumes start in January, April, July and October, but subscriptions may begin with any issue.

The direct postal price per subscription for one copy of NATURE each week is:

*12 MONTHS (52 issues and 4 indexes)

Great Britain and Eire......................14.0.0 each United States of America........ (by air freight) ........\$48 each Canada................. (by air freight) .......\$52 each Elsewhere overseas by surface mail..............14.0.0 each (Charge for delivery by air mail on application) * Shorter periods pro rata. (Minimum three months.)

\section{Other Countries}

Pharmaceutical Manufacturers Association. 1968 Annual Report. Py. 23. Washington, DC: Pharmaceutical Manufacturers Association, 1968.) [69 Rubber Research Institute of Malaya. Annual Report 1967. Pp. 113.
(Kuala Lumpur: Rubber Research Institute of Malaya, 1968.) $\$ 3$. The Year Book of the National Institute of Seiences of India, 1968. Pp. xii + 290. (New Delhi: National Institute of Sciences of India, 1968.) Republic of the Sudan. Ministry of Agriculture, Agricultural Research
Division. 1963-1964 Annual Report, for the season 1.July 1963 to 30 June 1964. Pp. 235. (Khartoum: Ministry of Agriculture, Agricultural Research
Division, 1968.) Division, 1968.) $[69$ of Canada Paper 68-11: Triassic Stratigraphy between Athabasca and Brazeau Rivers of Alberta. By D. W. Gibson. Pp. vi $+84 . \$ 2$. Paper 67-65; Triassic Stratigraphy between the Athabasca and Smoky Rivers of Alberta. By D. W. Gibson. Pp. v 114 (8 plates). \$2. Paper 68 37: A Recording Thermomagnetic Balance. By E. J. Schwarz. Pp. iv +11 \$1.50. Paper 68-39: Some Chemical Features of Lead-Zinc Deposits in Carbonate Rocks. By D. F. Sangster. Pp. iv +17 . \$1.50. Economic Greology-Report No. 24: Groundwater in Canada. By Officers of the Geological Survey of Canada. Edited by I. C. Brown. Pp. 228. \$7. Geological Maps-Preliminary Series. Map 19-1967: Gleichen, West of Fourth Meridian, Alberta. Map 20-1967: Lethbridge, West of Fourth Meridian,
Alberta. Map 22-1967: Foremost, West of Fourth Meridian, Alberta. (Ottawa: Queen's Printer, 1967 and 1968). Smithsonian Miscellaneous Collections. Vol, 153, No. 1: Morphology and (Pystematics of the Bryozoan Genus Metrarabdotos. By Alan H. Cheetham. sonian Institution Press, 1968.) Institut Royal Météorologique de Belgique. Publications, Série B, No. 53: Le Temps en 1967. Par Dr R. Sneyers. Pp. 52. (Uccle-Bruxelles: Jnstitut Royal Météorologique de Belgique, 1968.)

Fisheries Research Board of Canada. Bulletin 165: Carp in Canada. $\stackrel{199}{\text { By }}$ H. R. McCrimmon. Pp. ix + 94. (Ottawa: Queen's Printer, 1968.) \$2. [99 Le Conseil des Recherches Agricoles. Recherches Agronomiques-Sommaire des Résultats, 1966/1967. (No, 12, 1967.) Pp.71. (Québec: Ministère [99
de l'Agriculture et de la Colonisation du Québec, 1967.)
University of California Publications in Zoology, Vol. 85: Reproduction in Brown Lemmings (Lemmus trimucronatus) and Its Relevance to Thejr Cycle of Abundance. By David A. Mullen. Pp. 24. (Berkeley and Los Angeles: University of California Press; London: Cambridge University Press, 1968.) $\$ 1.50$.
Board of Grain Commissioners for Canada. Grain Research Laboratory 1967 Report. Pp. vi + 90. (Ottawa: Queen's Printer, 1968.) [99 Canada: Department of Energy, Mines and Resources. Bulletin 154: Deglaciation Studies in Kamloors Region, an Area of Moderate Relief British Columbia. By R, J. Fulton. Pp. 36. (10 plates.) \$2. Bulletin 164: Index and List of Titles, Fisheries Research Board of Canada and associated 67-51: Rocks and Minerals for the Collector, Kingston, Ontario to Lac StJean, Quebec. By Ann P. Sabina. Pp. xii +147. \$2. Paper 68-3: 19671968, Index of Publications of the Geological Survey of Canada. By D. Snowden. Pp. 75. Paper 68-23: Some Problems of the Quaternary Palynology in the Western Mainland Region of the Canadian Arctic. By J. Terasmae. Pp. $v+26$. \$1.50. Paper 68-35: The Petrology of the No. 10 By A. R. Cameron and S. K. Babu. Pp. vi +57. \$1.50. (Ottawa: Queen's Printer, 1967 and 1968.)
University of Michigan. Institute for Social Research-a Report on Recent Activities. Pp. 104. (Ann Arbor, Michigan: University of Michigan, 1968)
[99) Records of the Australian Museum. David K. McAlpine. Pp. 263-283. (Sydney: The Australian Museum, 1268.) A \$0.65.
Australia: Commonwealth Scientific and Industrial Research Organization. Mineral Chemistry-Research Report, 1967-68. Pp. 16. (Melbourne and Sydney: Division of Mineral Chemistry, CSIRO, 1968.) [109 Flora Zambesiaca-Supplement. Edited by H. Wild and A. Fernandes on behalf of the Editorial Board. Vegetation Map of the Flora Zambesiaca Area. Pp. $71+$ maps. (Salisbury, Rhodesia: M. O. Collins (Pvt.), Ltd.,
1968. Published on behalf of the Governments of Portugal, Malawi, Rhodesia and the United Kingdom.)

U.S. Department of Health, Education and Welfare. National Institutes of Health Publication No. 32: Thymolytic and Glycogenic Endocrine Bioassay Data, Entry Nos. 1698-4323 (Tssue 2, May 1968). Edited by Arthur G, Hilgar and Lois C.. Trench. Pp i 149. National Cancer Institute, Nationa Institutes of Health, 1968.)
[129 Institutes of Health, 1968.) Trustees and Director of the National Museums Rhodesia for the year ended 31st December, 1967. Pp. 25. (Salisbury: Trustees of the National Musenms, 1968.) Colony of Mauritius. Meteorological Observations and Climatological
Summaries. April 1967. Pp. 29. May, 1967. Pp. 34. June, 1967. Pp. 35. (Port Louis: Government Printer, 1968.)

Editorial and Publishing Offices of "NATURE" MACMILLAN (JOURNALS) LIMITED 4 LITTLE ESSEX STREET, LONDON, W.C.2.

Telephone Number: $01-836$ 6633. Telegrams: Phusis London W.C.2

Subscription Department MACMILLAN (JOURNALS) LIMITED BRUNEL ROAD, BASINGSTOKE, HANTS Telephone Number: Basingstoke 543I

Advertisements only should be addressed to T. G. SCOTT \& SON, LIMITED

I CLEMENT'S INN, LONDON, W.C.2. Telephone Number: $01-4054743$

Registered as a newspaper at the General Post Office

Copyright (C) Macmillan (Journals) Limited, October 12, 1968 